\title{
Analysis of the Implementation of Policies for Handling Emergency Covid 19 Infectious Diseases at Royal Prima Hospital Medan 2020
}

\author{
Heny ${ }^{1}$, Mangatas Silaen ${ }^{2 *}$, Tan Suyono ${ }^{3}$, Adhayani ${ }^{4}$ \\ $1,2,3,4$ Universitas Prima Indonesia \\ ${ }^{*}$ Corresponding Author: \\ Email: mangatassilaen@unprimdn.ac.id
}

\begin{abstract}
.
This study aims to analyze the implementation of the policy for handling the infectious disease covid 19 at the Royal Prima Medan Hospital in 2020. The sample in this study amounted to 69 people. All data is obtained by analysis so that the data can provide useful meaning to solve research problems. We use univariate Analysis, bivariate analysis, and multivariate analysis. The research result shows that there is no relationship between policies and commitments with handling Covid, there is a relationship between planning and handling Covid, there is no relationship between organizing and handling Covid, and there is a relationship between implementation and handling Covid. We hope that the hospital will support and carry out the implementation of the policy for handling the infectious disease covid 19 at Royal Prima Hospital for the sake of high-quality service results. Future researchers are expected to examine more sources and references related to the analysis of the implementation of the Covid 19 so that the research results can be better and more complete.
\end{abstract}

Keywords: Policy, Implementation, Covid 19, Disease

\section{INTRODUCTION}

The policies for controlling infectious disease outbreaks, Indonesia has Law Number 4 of 1984 concerning Outbreaks of Infectious Diseases, Government Regulation Number 40 of 1991 concerning Overcoming Outbreaks of Infectious Diseases, and Regulation of the Minister of Health Number 1501/Menkes/Per/X/2010 concerning Certain Types of Infectious Diseases That Can Cause Outbreaks and Countermeasures. For this reason, in the context of efforts to prevent the early COVID19 outbreak, the Minister of Health has issued a Decree of the Minister of Health Number HK.01.07 / MENKES / 104 / 2020 concerning the Determination of Novel Coronavirus Infection (2019-nCoV Infection) as a Type of Disease That Can Cause Outbreaks and Efforts to Overcome it. The determination is based on the consideration that the Novel Coronavirus Infection (2019-nCoV infection) has been declared by WHO as a Public Health Emergency of International Concern (PHEIC). In addition, the wide spread of COVID-19 to various countries with the risk of spreading to Indonesia related to population mobility requires efforts to overcome the disease (KMK RI, 2020). 
Coronavirus Disease 2019 (COVID-19) has been declared by WHO as a global pandemic and in Indonesia it is declared as a type of disease that causes public health emergencies and non-natural disasters, which not only cause death but also cause considerable economic losses, so it is necessary to take measures to prevent it. including prevention and control (KMK RI, 2020). The global situation of the total global COVID-19 confirmed cases as of November 30, 2020 was 62,363,527 cases with 1,456,687 deaths (CFR 2.3\%) in 219 infected countries and 180 local transmission countries (Ministry of Health, 2020). Globally the incidence of covid in the world, as of December 16, 2020, there were 72,196,732 confirmed cases of COVID-19, including 1,630,521 deaths, reported to WHO.(WHO, 2020). According to WHO in 2020, the incidence of Covid-19 In China, from January 3 to December 16, 2020, there were 95,279 confirmed cases of COVID-19 with 4,764 deaths. According to Worldometers, in 2020, the Covid death rate in Asian countries until February 3, 2021 was 504 deaths from 23,274,169 cases.

According to Worldometers, in 2020, the Covid death rate in European countries until February 3, 2021 was 1889 deaths from 30,609,642 cases.Based on Medan city health data in 2020, general data related to the city of Medan Covid-19 from April-November 2020, suspected as many as 11420 people with 10659 people returning home, 327 people died and 434 people were treated. While the positive confirmation of Covid-19 was 8066 people, of which 6768 people recovered, 327 people died and 971 people were treated. Royal Prima General Hospital Medan has negative isolation rooms 134 rooms and 4 mini ICU rooms with a total of 96 nurses. Based on work achievements, there were confirmed Covid patients: 371 patients (318 patients recovered, 6 patients referred, 2 PAPS patients, 45 patients died). Judging from the age of patients who were confirmed to have COVID-19, they were 60 years old (26\%) and 60 years old (74\%).Based on the above background, the researcher is interested in conducting research on the analysis of the implementation of the policy for handling the infectious disease covid 19 at the Royal Prima Hospital in Medan in 2020.

\section{LITERATURE REVIEW}

\subsection{Policy}

The policy is an applicable statute, characterized by consistent and reduced behavior, both from those who make and implement the policy (Sore, 2017). Policy is a series and principles that become the outline and basis of a plan in the implementation of a leadership job and a way of acting (about the organization), a statement of ideals, goals, principles or intentions as a guideline for management in an effort to achieve certain goals (Daci, 2017).

\subsection{Emerging infectious disease}

Emerging infectious disease EIDs are diseases that appear and attack a population for the first time, or have existed before but are increasing very rapidly, 
either in terms of the number of new cases in a population, or their spread to new geographic areas. Also grouped in EIDs are diseases that have occurred in an area in the past, then declined or have been controlled, but then reported again in increasing numbers. Sometimes an old disease appears in a new clinical form, which can be more severe or fatal. This disease is called an old disease (re-emerging) (Kemenkes, 2020).

Emerging infectious diseases are infectious diseases that are rapidly spreading in a human population, may originate from viruses, bacteria, or parasites. Most (75\%) emerging infectious diseases are transmitted to humans from animals (zoonotic diseases) (FMD, 2016).

\subsection{Covid 19}

SARS-CoV-2 is a new type of coronavirus that has never been previously identified in humans. There are at least two types of coronavirus that known to cause diseases that can cause severe symptoms such as Middle East Respiratory Syndrome (MERS) and Severe Acute Respiratory Syndrome (SARS). Common signs and symptoms of COVID-19 infection include symptoms of acute respiratory distress such as fever, cough, and shortness of breath. The average incubation period is 5-6 days with the longest incubation period being 14 days. In severe cases of COVID-19 it can cause pneumonia, acute respiratory syndrome, kidney failure, and even death (KMK, 2020).Corona Virus Disease 2019 (COVID-19) has been declared by the World Health Organization (WHO) as a pandemic and Indonesia has declared Corona Virus Disease 2019 (COVID-19) as a non-natural disaster in the form of a disease outbreak that must be taken care of so that there is no increase in cases. In order to prevention efforts are carried out by implementing health quarantine as regulated in Law Number 6 of 2018 concerning Health Quarantine. (PP RI, 2020).

\subsection{Epidemiology}

According to the $2020 \mathrm{KMK}$, Coronavirus Disease 2019 (COVID-19) is an infectious disease caused by a new type of Coronavirus. This disease began with the emergence of pneumonia cases of unknown etiology in Wuhan, China at the end of December 2019 ( $\mathrm{Li}$ et al, 2020). Based on the results of an epidemiological investigation, the case is suspected to be related to the Seafood Market in Wuhan. On January 7, 2020, the Chinese government later announced that the cause of the case was a new type of coronavirus which was later named SARS-CoV-2 (Severe Acute Respiratory Syndrome Coronavirus 2). This virus belongs to the same family as the viruses that cause SARS and MERS. Even though they come from the same family, SARS-CoV-2 is more infectious than SARS-CoV and MERS-CoV (CDC China, 2020).

\subsection{Coronavirus Transmission}

Coronavirus transmission is zoonotic (transmitted between animals and humans). Research says that SARS was transmitted from civet cats to humans and MERS from camels to humans. Meanwhile, the animal that is the source of COVID-19 transmission is still unknown. The average incubation period for COVID-19 is 5-6 
days, with a range between 1 and 14 days but can be up to 14 days. The highest risk of transmission is obtained in the first days of the disease due to the high concentration of virus in the secretions. Infected persons can be directly infectious up to 48 hours before symptom onset (presymptomatic) and up to 14 days after symptom onset. A study of $\mathrm{Du} \mathrm{Z}$ et. al, (2020) reported that $12.6 \%$ showed presymptomatic transmission. It is important to know the presymptomatic period because it allows the virus to spread through droplets or contact with contaminated objects. In addition, that there are asymptomatic confirmed cases, although the risk of transmission is very low, there is still a small possibility of transmission (KMK, 2020).

\subsection{Governance}

Hospital is a health service institution that provides complete individual health services that provide inpatient, outpatient, and emergency services (PMK RI, 2016). The hospital is one part of the health service system that broadly provides services for the community in the form of health services including medical services, medical follow-up services, medical rehabilitation and care services (Herlambang, 2017). According to the Regulation of the Minister of Health of the Republic of Indonesia Number 4 of 2018 concerning hospital obligations and patient obligations to provide correct information about hospital services to the public;

1. Providing safe, quality, anti-discriminatory, and effective health services by prioritizing the interests of patients in accordance with standards hospital services;

2. Provide emergency services to patients in accordance with their service capabilities;

3. Take an active role in providing health services in disasters, in accordance with their service capabilities;

4. provide facilities and services for the underprivileged or poor;

5. carry out social functions

6. create, implement, and maintain quality standards of health services in hospitals as a reference in serving patients;

7. maintain medical records;

8. provide proper public facilities and infrastructure including worship facilities, parking, waiting rooms, facilities for disabled people, breastfeeding women, children, the elderly;

9. implement a referral system;

10. reject the patient's wishes that are contrary to professional and ethical standards as well as statutory regulations;

11. provide true, clear and honest information regarding the rights and obligations of patients;

12. respect and protect patient rights 


\section{METHODS}

In this study, researchers used a quantitative approach with a survey method, namely by focusing on hypothesis testing and analyzed using the Chi Square test with the SPSS program. The population in this study were the director of the hospital, the head of the PIE team, the director of medical services, the head of nursing, and the medical support department. The sample in this study amounted to 69 people. All data is obtained by analysis so that the data can provide useful meaning to solve research problems. The data analysis that the authors do is 1) univariate Analysis; 2). Bivariate Analysis; and 3) Multivariate Analysis

\section{DISCUSSION}

\subsection{Policy analysis and commitment to the handling of infectious diseases covid 19 at Royal Prima Hospital Medan in 2020}

Statistically, it shows that the value is $0.455 \mathrm{df}=1$ with a significance value of 0.50 where $\mathrm{X} 2$ count $<\mathrm{X} 2$ table means $\mathrm{Ha}$ is rejected and Ho is accepted, meaning that there is no relationship between policies and commitments with handling Covid.Based on the results of the research conducted by the researcher, the researcher assumes that the existence of policies and commitments will not affect the handling of the Covid 19 emergency infectious disease at the Royal Prima Hospital Medan in 2020. Based on Purwaningsih's 2020 research on Health Policy Analysis Based on Risk Group Analysis of the Spread of Covid-19 Cases in Indonesia in 2020 where until the end of October 2020 corona cases in Indonesia reached 410,088 cases and 13,869 cases died.

DKI Jakarta is the province with the highest COVID-19 cases in Indonesia with 95,253 positive confirmed cases and has a high population density. The male sex has a higher number of cases, isolation, recovery and death than the female sex, each of which has more than $50 \%$ of cases. Productive adults aged $31-45$ years had the highest number of cases compared to other age groups with an accumulation of $30.9 \%$. The age group with the highest number of deaths was in the $>60$ year age group with $42.6 \%$. Government policies ranging from personal and environmental protection both written and unwritten (appeals) were made to reduce the number of Covid-19 cases in Indonesia.

\subsection{Analysis of planning for the handling of the infectious disease covid 19 at the Royal Prima Hospital in Medan in 2020}

Statistically, it shows that the value is $0.455 \mathrm{df}=1$ with a significance value of 0.50 where $\mathrm{X} 2$ count $>\mathrm{X} 2$ table means $\mathrm{Ha}$ is accepted and Ho is rejected, meaning that there is a relationship between planning and handling Covid.Based on the results of research conducted by researchers, researchers assume that planning is very influential on the handling of the infectious disease covid 19 at Royal Prima Hospital, Medan in 2020 . 


\subsection{Organizational analysis of the handling of infectious diseases covid 19 at Royal Prima Hospital Medan in 2020}

Statistically it shows that the value is $0.455 \mathrm{df}=1$ with a significance value of 0.50 where $\mathrm{X} 2$ count $<\mathrm{X} 2$ table means Ha is rejected and Ho is accepted, meaning that there is no relationship between organizing and handling Covid. Based on the results of the research conducted by the researcher, the researcher assumes that the existence of organization has no effect on the handling of the Covid 19 emergency infectious disease at Royal Prima Genera Hospital Medan.

According to Nasution's 2020 research on the Evaluation of Covid-19 Handling Policies in the City of Surabaya: Case Study of Large-Scale Social Restriction Policy Policy where this research suggests the need for massive institutional penetration to break the chain of disease spread by involving community participation.According to Toni's 2020 research on Organizational Communication Management in Public Relations and Protocols in State Institutions in the Pandemic Era. For Covid-2019, research results show that during the Covid-19 pandemic, there were many obstacles that occurred in public relations services and protocols at state institutions. With regulatory management and good understanding, public relations and protocol services can still be provided to the leadership optimally.

\subsection{Analysis of the application of the handling of the infectious disease covid 19 at the Royal Prima Hospital in Medan in 2020}

Statistically, it shows that the value is $0.455 \mathrm{df}=1$ with a significance value of 0.50 where $\mathrm{X} 2$ count $>\mathrm{X} 2$ table means Ha is accepted and Ho is rejected, meaning that there is a relationship between implementation and handling Covid. Based on the results of the research conducted by the researcher, the researcher assumes that the application has no effect on the handling of the Covid 19 emergency infectious disease at the Royal Prima Hospital in Medan in 2020. According to Sucitawathi's 2020 research on the Implementation of Community Activity Restriction (PKM) Policies in Combating the Covid-19 Outbreak in Denpasar City, the results of the study explained that the implementation of Restrictions on Community Activities policies in Denpasar City included several things, namely restrictions on community crowds, travel restrictions without wearing masks, movement community without a clear purpose, prohibition of four-wheeled vehicles full of passengers, restrictions on goods vehicle activities and restrictions on operating hours of business activities (shops). The implementation of the Restrictions on Community Activities (PKM) policy in dealing with the Covid-19 outbreak in Denpasar City has been running effectively.The involvement of the traditional village party is very helpful for the government's program in tackling Covid-19 because the village administrators through the banjar prajuru better understand the situation and condition of the community in their environment. The involvement of other agencies such as the TNI/Polri is very helpful for the creation of security and order during this time Restrictions on Community 
Activities take place. This Restrictions on Community Activities Restriction aims to suppress the positive number of Covid-19 in Denpasar.

\subsection{Multivariate Analysis Results}

To obtain the dominant factors related to the handling of the Covid 19 emergency infectious disease at Royal Prima General Hospital Medan in 2020, the analysis continued to multivariate analysis using multiple logistic regression tests. Based on the results of the overall analysis process that has been carried out, it can be concluded that the bivariate between each independent variable (commitment and policy, planning, organizing, implementing and handling covid) shows that the variable that has a p-value $<0.25$ is non-existent. It can be explained that the largest OR value is the application variable, which is 7,800 . This shows that the application is the most dominant variable related to the handling of the Covid 19 emergency infectious disease at the Royal Prima Hospital in Medan in 2020. It can be explained that the application states that the handling of the Covid 19 emergency infectious disease is good.

\section{CONCLUSIONS AND RECOMMENDATION}

\subsection{Conclusion}

Based on the results of the research on the analysis of the implementation of the COVID-19 emergency infectious disease management policy at Royal Prima Genera Hospital Medan in 2020, the following conclusions were drawn:

1. There is no relationship between policies and commitments with handling Covid..

2. There is a relationship between planning and handling Covid.

3. There is no relationship between organizing and handling Covid.

4. There is a relationship between implementation and handling Covid.

\subsection{Suggestion}

The researcher's suggestions from the research that has been carried out on "analysis of the implementation of the policy for handling the infectious disease covid 19 at the Royal Prima Hospital in Medan in 2020" are as follows:

\section{For Hospitals}

It is hoped that the hospital will support and carry out the implementation of the policy for handling the infectious disease covid 19 at Royal Prima Hospital for the sake of high-quality service results.

\section{For further researchers}

As for some suggestions that need to be considered for further researchers regarding the analysis of the implementation of policies for handling infectious diseases covid 19 at Royal Prima Hospital Medan in 2020. The Future researchers are expected to examine more sources and references related to the analysis of the implementation of the Covid 19 emergency infectious disease management policy at Royal Prima Genera Hospital Medan in 2020 so that the research results can be better and more complete. 


\section{REFERENCES}

[1] Kemenkes, 2019. https:// covid19. kemkes. go. id/ pengantar-infeksi emerging /\#.

[2] X8Msy80zbIU. Diakses tanggal 28 November 2020.

[3] KMK RI, 2020. PEDOMAN PENCEGAHAN DAN PENGENDALIAN CORONAVIRUS DISEASE 2019 (COVID-19). Jakarta.

[4] Herlambang. 2017. Cara Mudah Memahami Manajemen Kesehatan Dan Rumah Sakit.Gosyen Publishing : Yogyakarta

[5] Kemenkes,2020.

https://covid19.kemkes.go.id/situasi-infeksi-emerging/info-corona-virus/situasi-terkiniperkembangan-coronavirus-disease- covid-19-01-desember-2020/\#.X8Zeic0zbIU. Diakses tanggal 1 desember 2020.

[6] KMK RI, 2020. Pedoman Pencegahan Dan Pengendalian Coronavirus Disease 2019 (COVID-19).Jakarta.

[7] Sore. 2017. Kebijakan Publik. CV Sah Media . Makasar

[8] PMK, 2016. Peraturan menteri kesehatan republik indonesia nomor 59 tahun 2016 tentang pembebasan biaya pasien penyakit infeksi emerging tertentu. Jakarta.

[9] PP, 2020. Peraturan pemerintah republik indonesia nomor 21 tahun 2020 tentang pembatasan sosial berskala besar dalam rangka percepatan penanganan

[10] corona wrus disease 2019 (covid-ig). Jakarta.

[11] Dachi, 2017. Proses dan analisis kebijakan kesehatan. CV budi Utama. Sleman Alvioletta, 2020. Penerapan metode hierarchy process (AHP). CV.Tirta Kemcana.

[12] Nyawang.

[13] Maryono, 2018. Istialh -istilah dalam kebijakan dan manajemen kesehatan. Qiara Media. Ibeng, 2020. https://pendidikan.co.id/pengertian-perencanaan- fungsi-tujuanbeserta-jenisnya/. Diakses tanggal 116 desember 2020.

[14] WHO,2020. https://covid19.who.int/region/wpro/country/cn, Diakses tanggal16 Desember 2020.

[15] Worldometers, 2020. https://www.worldometers.info/coronavirus/. Diakses tanggal 16 Desember 2020.

[16] Dinkes,2020.https://covid19.pemkomedan.go.id/index.php?page=stat_medan. Diakses tanggal 15 Desember 2020.

[17] Nasution, 2021. Evaluasi Kebijakan Penanganan Covid-19 Di Kota Surabaya: Studi Kasus Kebijakan PSBB. Jurnal Ilmu Sosial Dan Humaniora. 4 (1).

[18] Purwaningsih, 2020. Analisis Kebijakan Kesehatan Berdasarkan Analisis Kelompok Risiko Terhadap Persebaran Kasus Covid-19 Di Indonesia Tahun 2020. Jurnal Kebijakan Kesehatan Indonesia. 10 (2).

[19] Toni, 2020. Manajemen Komunikasi Organisasi Pada Hubungan Masyarakat Dan Protokol Dalam Lembaga Negara Di Era Pandemi Covid-2019. Public Relations Journal. 1 (1).

[20] Sucitawathi tahun 2020 tentang Penerapan Kebijakan Pembatasan Kegiatan Masyarakat (PKM) Dalam Penanggulangan Wabah Covid-19 Di Kota Denpasar. Jurnal Moderat . $6(3)$. 